\title{
Simulasi Kalkulator Energi Baru Terbarukan (EBT) Guna Memenuhi Ketahanan Energi di Indonesia
}

\author{
REZZY EKO CARAKA ${ }^{1}$, PUTI CRESTI EKACITTA ${ }^{2}$ \\ ${ }^{1}$ Departemen Statistika, Universitas Diponegoro, Semarang. \\ 2Kementerian Energi dan Sumber Daya Mineral \\ Rezzyekocaraka@gmail.com
}

\begin{abstract}
ABSTRAK
Ketahanan Energi adalah suatu kondisi terjaminnya ketersediaan energi, akses masyarakat terhadap energi pada harga yang terjangkau dalam jangka panjang dan tidak terpengaruh oleh gejolak regional maupun internasional. Menjadi negara maju, Indonesia harus dapat mendorong sektor industri sebagai penggerak perekonomian negara. Kebutuhan energi di sektor industri dan komersial diprakirakan tetap mendominasi untuk jangka panjang. Sebagai sektor penunjang pergerakan perekonomian, sektor transportasi juga terus meningkat.Konsumsi energi menurut jenis selama tahun 2000 sampai dengan 2015 masih didominasi oleh BBM (avtur,avgas,bensin,minyak tanah, minyak solar, minyak diesel, dan minyak bakar). Permasalahan energi yang terjadi saat ini adalah dibutuhkan alternatif baru yang dikenal sebagai energi baru terbarukan (EBT). Berdasarkan analisis

dengan single exponential smoothing (SES) dengan menggunakan $\alpha=0.359680$ dapat disimpulkan bahwa perencanaan energi perlu dilakukan supaya dapat menjamin ketersediaan energi dengan harga terjangkau untuk jangka panjang. Potensi energi terbarukan seperti tenaga air,panas bumi, angin, surya, samudera, maupun biomasa dapat dijadikan alternatif untuk memenuhi permintaan energi yang semakin tinggi. Berdasarkan skenario dasar, penyediaan EBT meningkat dengan pertumbuhan lebih dari 14\% per tahun atau meningkat lebih dari enam kali lipat dari 102 juta SBM pada 2012 menjadi 629 juta SBM pada 2035. Pada 2012, sebagian besar dari EBT dipenuhi oleh dari biomasa, diikuti oleh tenaga air, panas bumi, dan BBN. Namun pada akhir periode 2035, panas bumi untuk pembangkitan listrik akan menjadi EBT utama, disusul secara berturut turut oleh hidro, BBN, dan biomasa. Jenis EBT yang lainnya seperti CBM, CTL, angin, tenaga surya, nuklir, dan kelautan yang sebelumnya tidak muncul di tahun 2015 mulai mengisi bauran energi nasional, walaupun persentasenya masih kecil.
\end{abstract}

Kata Kunci: Ketahanan energi, energi baru terbarukan (EBT), scenario, single eksponential smoothing (SES), Kalkulator energy

\section{PENDAHULUAN}

Dalam upaya mewujudkan kesejahteraan yang berkeadilan bagi seluruh rakyat Indonesia, UUD Tahun 1945 melalui pasal 33 telah mengamanatkan bahwa bumi dan air dan kekayaan alam yang terkandung di dalamnya dikuasai oleh negara dan dipergunakan untuk sebesar besarnya demi kemakmuran rakyat. Salah satu kekayaan alam yang memiliki nilai strategis bagi pembangunan nasional secara berkelanjutan adalah energi. Indonesia kaya akan berbagai jenis energi baik yang berbasis fosil maupun nonfosil. Saat ini penggunaan energi di Indonesia hanya bergantung pada energi fosil saja seperti BBM, karena itu cadangan energi fosil nasional bahkan dunia sangat terbatas dan lambat laun akan habis.

Jika kita melihat lebih jauh ke potensi energi terbarukan, Indonesia masih dianugerahi berkah luar biasa. Hal ini bisa dilihat dengan melimpahnya sinar matahari (Tenaga surya), geografis Indonesia sebagai negara maritim (Tenaga air), hingga banyaknya gunung berapi (energi panas bumi). Potret ketergantungan pada sumber daya alam tidak terbarukan (fosil), khususnya minyak bumi dapat dilihat pada Bauran Energi Indonesia. Pada tahun 2006 minyak bumi masih mendominasi bauran energi primer nasional (52\%). Respon terhadap situasi ini telah ditetapkan oleh pemerintah melalui Target bauran energi nasional,yang mana, bauran energi nasional .akan mengalami perubahan dan lebih mengutamakan pada energi terbarukan. 
Ketergantungan perekonomian nasional terhadap minyak dan gas bumi sebagai andalan sumber penerimaan negara harus segera dikurangi mengingat ketersediaan, potensi dan sumber daya minyak dan gas bumi sudah semakin menipis, disisi lain Indonesia memiliki variasi ketersediaan potensi dan sumber daya energi lain seperti batubara. Penelitian terakhir yang dilakuan oleh Caraka dan Yasin (2014), gas bumi memiliki potensi besar untuk dikembangkan, untuk itu pemerintah dalam rangka mendukung perencanaan pasokan gas untuk pemenuhan kebutuhan dalam negeri melakukan kajian dan menetapkan kebijakan yang mendukung dan menetapkan Rencana Induk Jaringan Transmisi dan Distribusi Gas Bumi Nasional serta memprioritaskan pemanfaatan melalui kebijakan penetapan alokasi dan pemanfaatan gas bumi dalam negeri. Produksi gas bumi masih belum optimal, saat ini hanya mampu diproduksi 1500 mmscfd (Milion Metric Standard Cubic Feet Per Day). Kalau saat ini industri meminta pasokan gas lebih dari 2000 mmscfd maka hanya mampu menyumbang $75 \%$ dari kebutuhan industri. Sehingga untuk memenuhi kebutuhan industri pemerintah harus mencari sumber energi gas alternatif.

Kondisi penggunaan energi fosil seperti minyak bumi pada tahun 2013 mencapai $46 \%$, gas bumi menyumbang sebesar $18 \%$, dan batubara sebesar 31\%. Sementara penggunaan energi baru terbarukan masih sangat kecil sebesar $5 \%$. Padahal Kementerian Energi dan Sumber Daya Mineral menargetkan penggunaan energi baru terbarukan untuk tahun 2025 yang tertuang dalam Peraturan Pemerintah No.79 tahun 2014 tentang Kebijakan Energi Nasional sebesar $23 \%$, penggunaan minyak bumi sebesar $25 \%$, batu bara sebesar $30 \%$ dan gas alam sebesar $22 \%$ (Handbook of Energi \& Economic Statistics of Indonesia KESDM, 2014). Sedangkan kebutuhan energi saat ini masih didominasi oleh energi fosil, menurut Handbook of Energi \& Economic Statistics of Indonesia (KESDM 2014) ketersediaan jumlah energi untuk minyak bumi sebesar 612 juta SBM, batubara 411 juta SBM, gas bumi 243 juta SBM, untuk jumlah energi baru terbarukan : tenaga air 43 juta SBM, panas bumi 15 juta SBM, dan bahan bakar nabati 5 juta SBM.

Dalam kondisi seperti itu kebijakan konservasi dan diversifikasi energi yang telah dicanangkan oleh pemerintah merupakan kebijakan yang tepat untuk diterapkan di Indonesia. Oleh karenanya pengembangan energi baru terbarukan (EBT) sebagai komplementer energi berbasis fosil , bersifat mutlak untuk terus dilaksanakan. Guna mendukung kebijakan ini, hal penting yang perlu terus diupayakan adalah konsistensi, komitmen, dan perubahan mindset dari pemerintah dan seluruh rakyat Indonesia bahwa sumber energi bukan hanya BBM atau batu bara atau gas saja, melainkan juga air, gelombang laut, angin, matahari, panas bumi, bahan bakar nabati, nuklir dan limbah sampah.

\section{TINJAUAN PUSTAKA}

\section{Ketahanan Energi}

Ketahanan energi adalah suatu kondisi terjaminnya ketersediaan energi, akses masyarakat terhadap energi pada harga yang terjangkau dalam jangka panjang dan tidak terpengaruh oleh gejolak regional maupun internasional (Tumiran, 2013). Dengan demikian, ketahanan energi nasional harus harus dipandang sebagai suatu proses yang dinamis dan berkelanjutan, untuk itu harus didukung oleh pengembangan EBT. Konsumsi energi listrik mengalami pertumbuhan rata - rata $6.2 \%$ per tahun, hal ini menyebabkan rasio elektrifikasi nasional masih rendah (Outlook Energi Indonesia BPPT, 2014).

\section{Potensi Sumber Daya Energi Baru Terbarukan}

Potensi energi terbarukan seperti tenaga air, panas bumi, angin, surya, samudera, maupun biomassa jumlahnya cukup memadai namun tersebar. Berdasarkan data KESDM (2013), cadangan panas bumi Indonesia sebesar 16.484 MW dari potensi sekitar 28.617 MW, sementara itu potensi biomassa untuk kelistrikan mencapai $49.8 \mathrm{GWe}$, potensi tenaga surya mencapai 12.1 MWe. Potensi tenaga air yang dimiliki Indonesia sebesar $500 \mathrm{MWe}$. 
Tabel 1. Ringkasan sumber energi baru terbarukan di Indonesia

\begin{tabular}{|c|l|c|c|}
\hline No & \multicolumn{1}{|c|}{ Sumber Energi } & Potensi & Kapasitas Terpasang \\
\hline 1. & Panas Bumi & $16.502 \mathrm{MW}$ & $1.341 \mathrm{MW}$ \\
\hline 2. & Hidro & $75.000 \mathrm{MW}$ & $7.059 \mathrm{MW}$ \\
\hline 3. & Mini mikrohidro & $767.7 \mathrm{MW}$ & $512 \mathrm{MW}$ \\
\hline 4. & Biomasa & $13.662 \mathrm{Mwe}$ & $1.364 \mathrm{Mwe}$ \\
\hline 5. & Energi surya & $4.80 \mathrm{kWh} / \mathrm{m} 2 / \mathrm{day}$ & $42.78 \mathrm{MW}$ \\
\hline 6. & Energi angin & $3-6 \mathrm{~m} / \mathrm{s}$ & $1.33 \mathrm{MW}$ \\
\hline 7. & Uranium & $3000 \mathrm{MW}$ & $30 \mathrm{MW}$ \\
\hline 8. & Gas metana batubara & $453 \mathrm{TSCF}$ & - \\
\hline 9. & Shale gas & $574 \mathrm{TSCF}$ & - \\
\hline
\end{tabular}

Sumber : Outlook Energi Indonesia BPPT, 2014

\section{Peramalan (Forecasting)}

Peramalan adalah kegiatan untuk memperkirakan apa yang akan terjadi di masa yang akan datang (Makridakis, 1999). Sedangkan menurut Awat (1990) yang dimaksud dengan meramal (to forecast) adalah suatu kegiatan atau usaha untuk mengetahui peristiwa-peristiwa yang akan terjadi pada waktu yang akan datang mengenai obyek tertentu dengan menggunakan judgment, pengalaman-pengalaman ataupun data historis, dengan demikian peramalan merupakan proses atau metode dalam meramal suatu peristiwa yang akan terjadi pada masa yang akan datang dengan mendasarkan diri pada variabel-variabel tertentu. Prosedur pemulusan (smoothing) eksponensial menurut Makridakis (1999) merupakan suatu metode yang menunjukkan pembobotan yang menurun secara eksponensial terhadap nilai observasi yang lebih tua. Metode pemulusan (smoothing) eksponensial terdiri atas tunggal, ganda, dan metode yang lebih rumit. Semuanya mempunyai sifat yang sama, yaitu nilai yang lebih baru diberikan bobot yang relatif lebih besar dibanding nilai observasi yang lebih lama. Menurut Rosadi (2012) metode ini hanya untuk data tanpa komponen trend dan/atau musiman serta digunakan hanya untuk peramalan satu satuan waktu ke depan. Metode pemulusan eksponensial tunggal adalah sebagai berikut:

$F_{t+1}=F_{t}+\alpha\left(X_{t}-F_{t}\right)$

dimana:

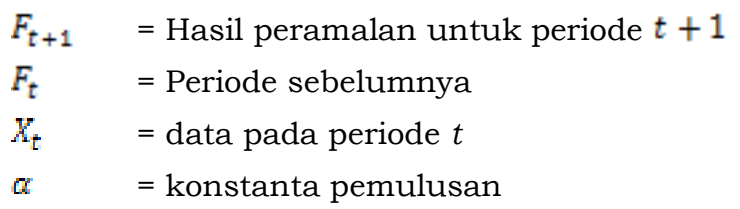

Nilai $\alpha$ diperoleh melalui cara trial and error hingga menemukan nilai MSE terkecil (Makridakis, 1999).

\section{Ketepatan Peramalan}

Menurut Makridakis (1999), dalam banyak situasi peramalan, ketepatan dipandang sebagai kriteria penolakan untuk memilih suatu metode peramalan. Kata ketepatan menunjuk ke "kebaikan suai", yang pada akhirnya penunjukkan seberapa jauh model peramalan tersebut mampu mereproduksi data yang telah diketahui. Menurut Makridakis (1999) jika Xi merupakan data aktual untuk periode $i$ dan $F_{i}$ merupakan ramalan (nilai kecocokan/ fitted value) untuk periode yang sama, maka kesalahan didefinisikan sebagai berikut:

$$
e_{\mathrm{t}}=X_{\mathrm{i}}-F_{\mathrm{i}}
$$




$$
\text { MSE }=\sqrt{\frac{\sum_{i=1}^{n} e_{i}^{2}}{n}}
$$

dimana:

$X_{i}$ : data sebenarnya periode ke $i$

$F_{i:}$ ramalan periode ke $i$

\section{Kalculator Energi dan Analisis Skenario}

Kalkulator energi merupakan suatu pengembangan teknologi yang berbasis spreadsheet dan weeb tools bertujuan untuk meramalkan penggunaan, dan persediaan energi sampai tahun 2050. Kalkulator energi pertama kali diperkenalkan oleh UK Department of Energi and Climate Change. Sebagai contoh, pengguna energi dapat meningkatkan pasokan energi dengan membangun lebih banyak pembangkit nuklir dan turbin angin, atau mengurangi permintaan energi dengan melakukan penghematan penggunaan energi di berbagai sektor. Ada tiga versi kalkulator energi 2050 yaitu:

1. My 2050 simulasi

2. Web tool

3. Spreadsheet

Cakupan dari kalkulator energi ini adalah teknologi, bahan bakar, penyediaan dan penggunaan energi dan menghasilkan emisi antara tahun 2010 dan 2050. Secara khusu:

$>$ Di sisi pasokan energi, termasuk pembangkit listrik, sumber energi primer (bahan bakar fosil, uranium dan biomassa) serta jaringan transmisi

$>$ Di sisi permintaan energi, termasuk pengguna energi (sistem pemanas, sektor industri) dan penghematan penggunaan bahan bakar.

Dalam pemodelan kalkulator energi menggunakan tahun dasar (base year) yaitu tahun 2011 dan dibuat skema dalam beberapa skenario atau level yaitu level 1, 2, 3 dan 4 .

\section{PERMASALAHAN}

Secara umum sektor energi saat ini menghadapi tantangan baik secara global maupun dalam lingkup nasional, beberapa permasalahan aktual saat ini diantaranya:

1. Produksi minyak terus menurun sementara permintaan energi terus tumbuh menyebabkan peningkatan impor minyak mentah dan produk olahan. Di sisi lain, subsidi BBM relatif tinggi, disebabkan oleh peningkatan konsumsi domestik, kenaikan harga minyak internasional dan penurunan nilai tukar rupiah terhadap dollar AS dan valuta asing lainnya.

2. Potensi yang dimiliki Indonesia cukup besar, tetapi pemanfaatan gas bumi dalam negeri masih terbatas.

3. Secara umum pemanfaatan energi terbarukan masih relatif kecil.

\section{METODE PENILITIAN}

Data yang digunakan dalam penilitian ini adalah data sekunder yang bersumber dari Kementerian ESDM. Data yang digunakan adalah data time series mulai dari tahun 1999 sampai dengan 2011.

Langkah-langkah dalam penelitian ini yaitu

1. Pada building model dilakukan langkah-langkah sebagai berikut
a. Plot data
b. Identifikasi plot data
c. Identifikasi model
d. Perhitungan akurasi
e. Melakukan peramalan 
2. Analisis Skenario Cadangan Energi Terbarukan menggunakan kalkulator energi 2050 dengan beberapa level yaitu level 1, 2, 3, dan 4 .

\section{ANALISIS}

\section{Metode Peramalan Single Exponential Smoothing untuk Menggambarkan Kebutuhan Energi di Tahun 2015}

Ketahanan Energi adalah suatu kondisi terjaminnya ketersediaan energi, akses masyarakat terhadap energi pada harga yang terjangkau dalam jangka panjang dan tidak terpengaruh oleh gejolak regional maupun internasional. Langkah pertama untuk melihat kondisi energi pada tahun 2015 dilakukan peramalan selama 4 tahun. Pada tahun 2015 di ramalkan bahwa minyak Bumi memberikan kontribusi yang paling besar untuk memenuhi kebutuhan energi dan energi panas bumi memiliki kontribusi yang sedikit. Potensi tenaga air adalah menjadi perhatian utama

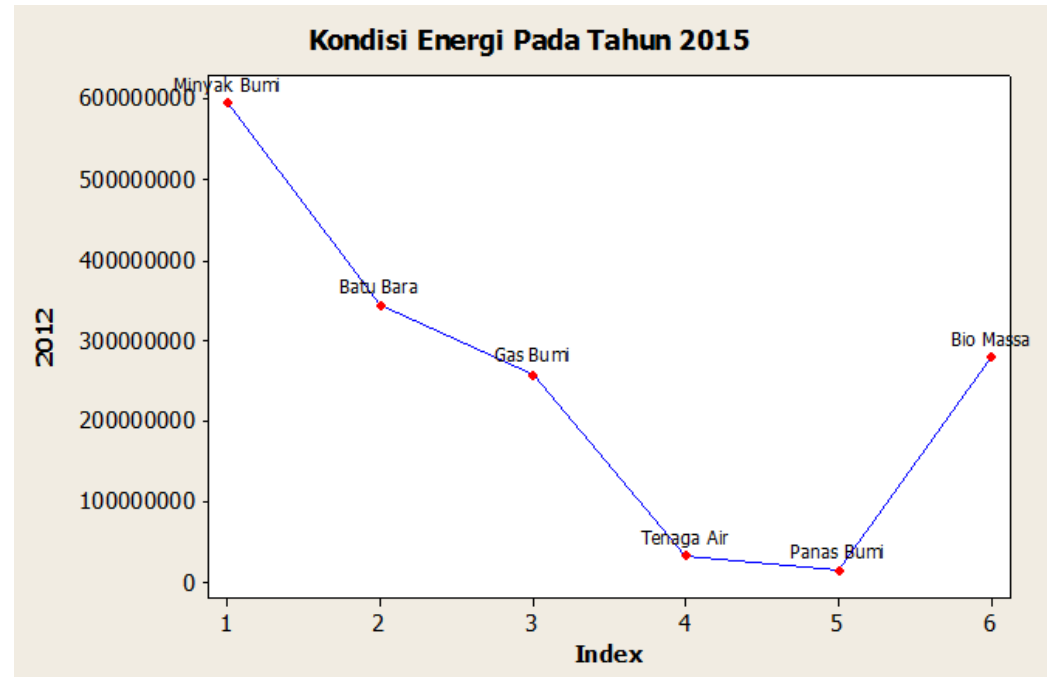

Gambar 1. Kondisi Energi pada Tahun 2015

Berikut adalah grafik peramalan menggunakan metode single exponential smoothing dengan nilai $\alpha=0.359680$

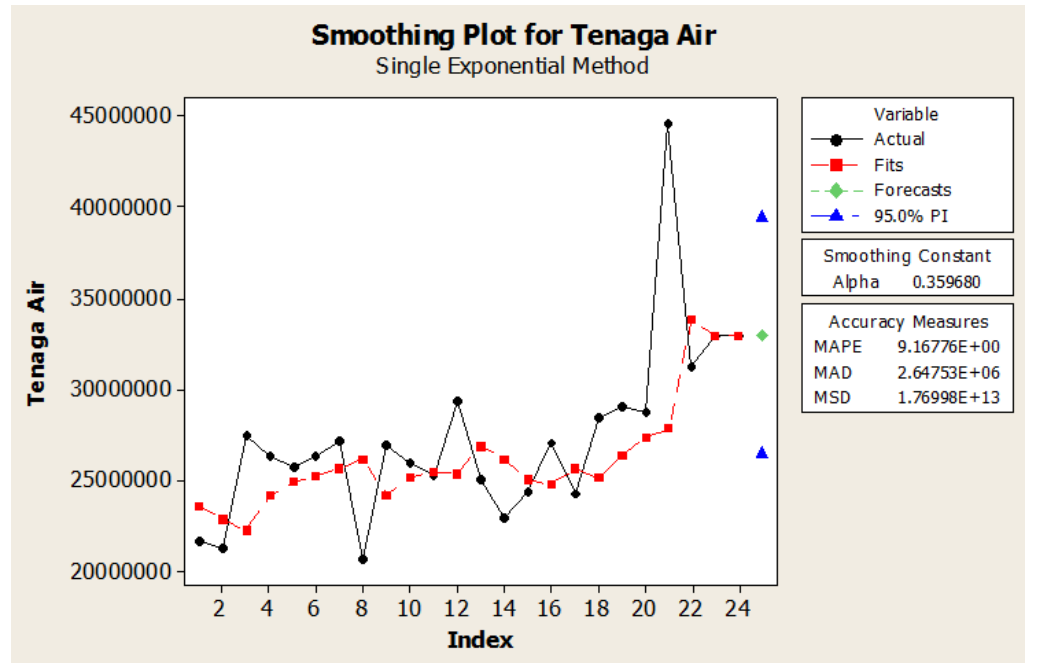

Gambar 2. Hasil Peramalan Single Exponential Smoothing untuk Tenaga Air 


\section{Rezzy Eko Caraka, Puti Cresti Ekacitta}

Setelah dilakukan plot data selanjutnya dilakukan pemodelan data energi tenaga air dengan menggunakan metode Single Exponential Smoothing (SES), model yang didapat adalah sebagai berikut:

$$
F_{t+1}=\alpha * X_{t}+(1-\alpha) * F_{t}
$$

dengan :

$\mathrm{Ft}=$ peramalan untuk periode $\mathrm{t}$

$X_{t}+(1-\alpha)=$ Nilai Aktual Time series

$F_{t+1}=$ peramalan pada waktu $\mathrm{t}+1$

$\alpha=$ konstantas perataan antara 0 dan 1

Sehingga didapat bahwa energi Tenaga Air yang dapat dihasilkan pada tahun 2015 sebesar 32909099. Pada 2015, sebagian besar dari EBT dipenuhi oleh dari biomasa, diikuti oleh tenaga air, panas bumi.

\section{Kalkulator Energi 2050 Gambaran Kondisi Keenergian Indonesia}

\section{a. Sumber Energi Fosil}

1. Produksi Batubara

Indonesia memiliki sumber daya batubara kurang lebih 119 juta ton. Pada tahun 2011 produksi batu bara Indonesia mencapai 353 juta ton dan dari jumlah tersebut sebagian besar kurang lebih 77 \% diekspor. Saat ini, dalam kebijakan energi nasional sudah mendapat arahan mengenai sumber daya energi, dimana sumber daya energi tidak dijadikan sebagai komoditas ekspor semata, tetapi sebagai modal pembangunan nasional.

Level 1

Level satu mengasumsikan produksi batu bara pada tahun 2050 sebsar 520 juta ton dengan peningkatan produksi sebesar $1 \%$ per tahun. Adanya kebijakan ini produksi batubara digunakan mayoritas untuk sektor ketenagalistrikan dan industri dalam negeri.

Level 2

Pada level ini mengasumsikan produksi batubara pada tahun 2050 sebesar 764 juta ton dengan peningkatan produksi sebesar $2 \%$.

Level 3

Di level ini mengasumsikan produksi batubara pada tahun 2050 sebesar 1.117 juta ton dengan peningkatan produksi $3 \%$ per tahun. Diasumsikan pengembangan diversifikasi energi berbasisi batubara pada gasifikasi guna menunjang sektor ketenagalistrikan.

Level 4

Level 4 mengasumsikan produksi batubara tahun 2050 sebesar 1.629 juta ton dengan kenaikan produksi sebesar $4 \%$. Produksi batubara digunakan terutama untuk memenuhi kebutuhan sekto ketenagalistrikan yang sangat tinggi untuk sektor industri yang jumlahnya terus meningkat.

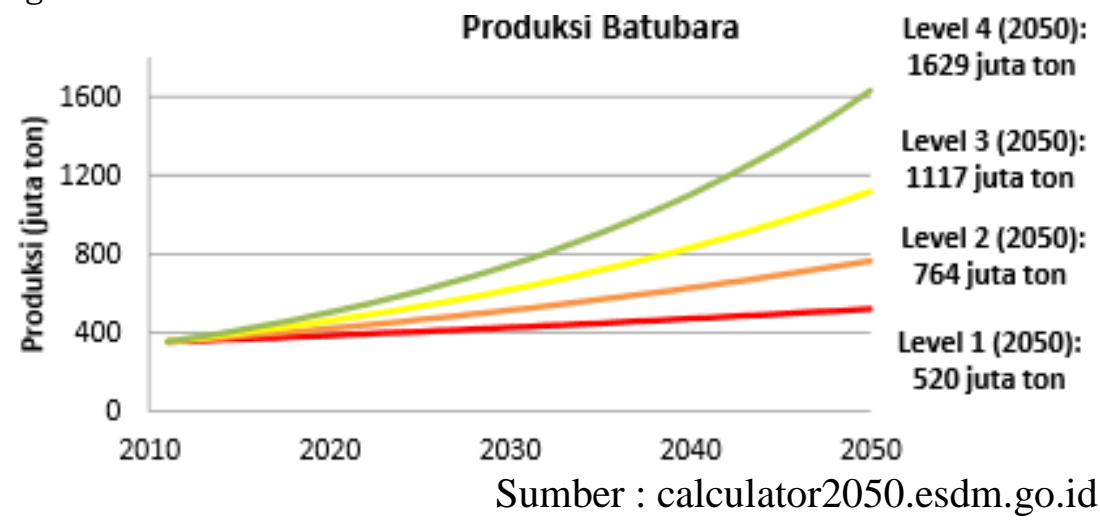

Gambar 3. Grafik Produksi Batubara Level I - II. 


\section{Produksi Minyak Bumi}

Indonesia sempat menjadi negara pengekspor minyak. Namun kini produksi minya terus mengalami penurunan dan bahkan berbalik menjadi pengimpor minyak. Pada tahun 2006, Indonesia masih bisa mempertahankan produksi diatas 1 juta bpd (barrel per haru), produksi terus mengalami penurunan hingga tahun 2011 produksi minyak Indonesia sebesar $902 \mathrm{bpd}$.

Level 1

Level 1 mengasumsikan produksi minyak bumi pada tahun 2050 mencapai 82 ribu bpd. Jumlah ini diperoleh dari laju penurunan produksi yang dapat ditahan pada angka $6 \%$ dari produksi saat ini (860 ribu bpd). Diasumsikan cadangan minyak pada lapangan lapangan eksisting telah habis, namun dengan adanya pengembangan lapangan baru maka laju produksi dapat ditahan pada angka $6 \%$.

Level 2

Level 2 mengasumsikan produksi minyak bumi pada tahun 2050 mencapai 180 ribu bpd. Jumlah ini diasumsikan berasal dari penambahan produksi blok Cepu dan Bukit Tua pada tahun 2015 sebesar 130 ribu bpd.

Level 3

Level 3 mengasumsikan produksi minyak bumi pada tahun 2050 mencapai 454 ribu bpd, jumlah ini diasumsikan berasal dari penambahan produksi dan proyek Enhanced Oil Recovery (EOR).

Level 4

Pada level ini produksi minyak bumi mencapai 1 juta bpd, jumlah ini diasumsikan berasal dari penambahan produksi sebesar $23 \%$ dari potensi, juga adana proyek offshore pada tahun 2030, 2035 dan 2040.

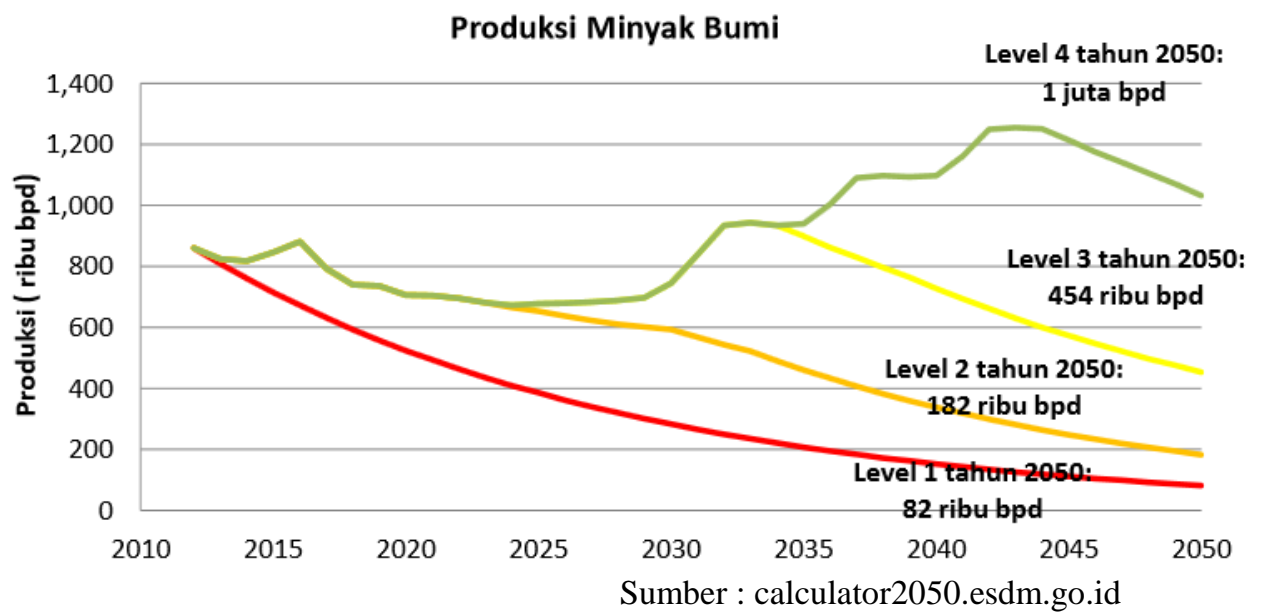

Gambar 4. Grafik Produksi Minyak Bumi Level I - IV

3. Produksi Gas Bumi

Indonesia hingga saat ini memiliki cadangan gas bumi kurang lebih 150.700 bscf (billion standard cubic feet), yang terdiri dari cadangan terbukti sebesar 103.300 bscf dan cadangan potensial sebesar 47.400 bscf. Produksi gas bumi pada tahun dasar (2011) sebesar 7.181 mmscfd, di samping gas konvensional Indonesia memiliki potensi cadangan gas non konvensional, berdasarkan penelitian Ditjen Migas dan Advance Resources International, Inc pada tahun 2003, sumber daya gas non konvensional berupa Coal Bed Methane (CBM) disinyalir sekitar $453 \mathrm{TCF}$ (trillion cubic feet).

Level 1

Mengasumsikan produksi gas bumi pada tahun 2050 sebesar $371 \mathrm{mmscfd}$, dengan adanya pengembangan lapangan.

Level 2

Level 2 mengasumsikan produksi gas bumi pada tahun 2050 diproyeksikan sebesar 968 mmscfd. Produksi tersebut berasal dari penambahan produksi product supply, antara lain Donggi Senoro, Masela, IDD dan Tangguh. 


\section{Rezzy Eko Caraka, Puti Cresti Ekacitta}

Level 3

Pada level ini produksi gas bumi pada tahun 2050 sebesar 5224 mmscfd. Produksi tersebut berasal dari tambahan produksi, antara lain project supply dan potential supply.

Level 4

Level 4 mengasumsikan produksi gas bumi pada tahun 2050 sebesar 9479 mmscfd. Produksi tersebut berasal dari tambahan produksi, antara lain project supply dan potential supply, penemuan gas baru sekitar $34 \%$ dari potensi dan produksi CBM sebesar $4 \%$.

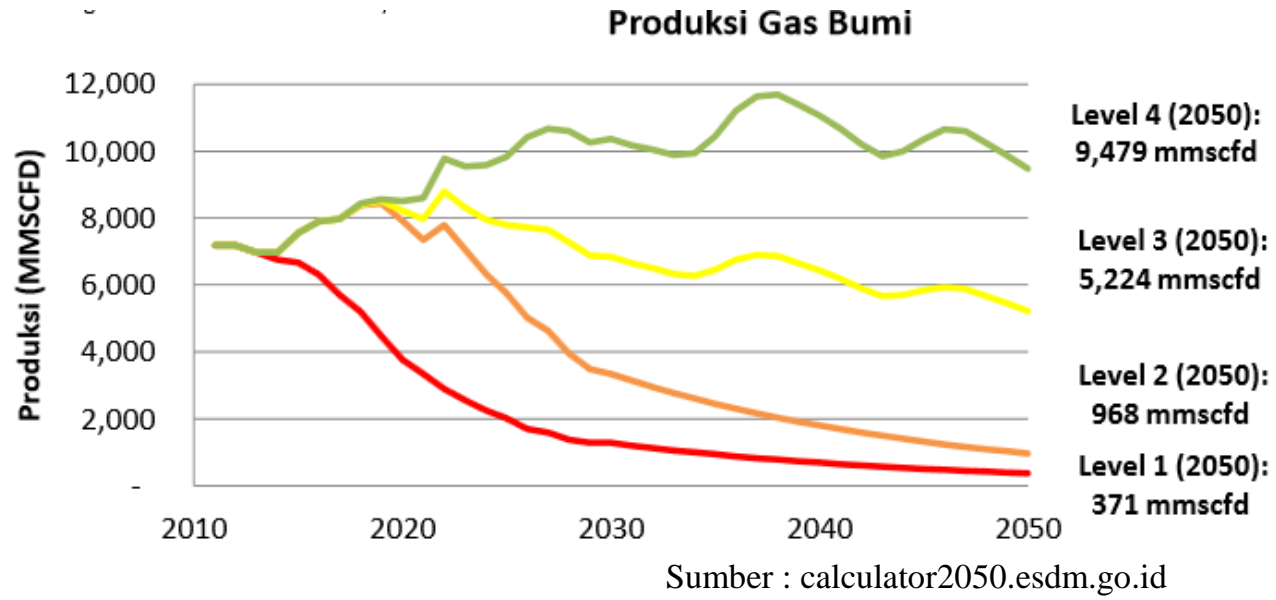

Gambar 5. Grafik Produksi Gas Bumi Level I - IV

b. Sumber Energi Baru Terbarukan

1. Panas Bumi

Potensi panas bumi Indonesia sebesar 28.91 GW yang mencakup $40 \%$ potensi panas bumi dunia. Lokasi panas bumi menyebar kurang lebih di 285 lokasi. Saat ini potensi panas bumi yang telah dimanfaatkan baru berada di 9 wilayah kerja dengan 5 lokasi diantaranya di Pulau Jawa. Kapasitas PLTP terbesar berada di wilayah Cibereum Jabar dengan kapasitas terpasang $0.377 \mathrm{GW}$. Total kapasitas terpasang di tahun 2011 hanya mencapai $1.21 \mathrm{GW}$ atau sekitar 4.2 $\%$ dari total potensi.

Level 1

Mengasumsikan kapasitas pembangkit panas bumi di tahun 2050 sebesar 5.78 GW atau $20 \%$ dari potensi.

Level 2

Mengasumsikan peningkatan kapasitas masih belum signifikan, namun lebih tinggi dari pada level 1, menjadi $8.67 \mathrm{GW}$ di tahun 2050, masih terdapat kendala pengembangan panas bumi.

Level 3

Mengasumsikan kapasitas terpasang PLTP pada tahun 2050 adalah 14.46 GW atau $50 \%$ dari potensi.

Level 4

Level 4 mengasumsikan kapasitas terpasang PLTP pada tahun 2050 mencapai $20.24 \mathrm{GW}$ atau $70 \%$ dari potensi. Pada level ini pembangunan PLTP sudah tidak menemui kendala. 


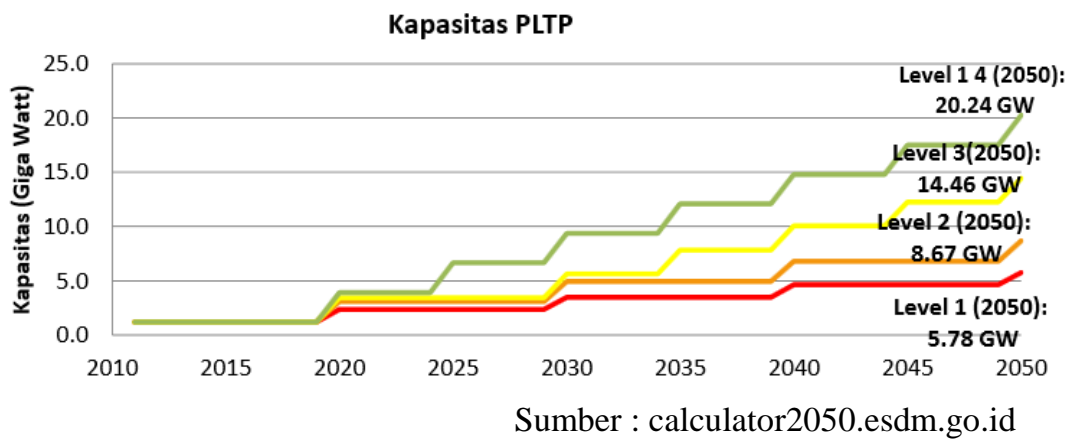

2. Biomassa

Gambar 6. Grafik Kapasitas PLTP Level I - IV

Indonesia memiliki kekayaan dan potensi bioenergi yang sangat melimpah. Potensi produksi biomassa mencapai 146.7 juta ton per tahun. Dalam kalkulator 2050 ini pembangkit biomassa diperoleh dari biomassa kering dan sektor kehutanan, pertanian dan perkebunan. Potensi kapasitas listrik yang dapat dihasilkan dari sektor tersebut mencapai $24.64 \mathrm{GW}$

Level 1

Level 1 mengasumsikan kapasitas terpasang PLT Biomassa pada tahun 2050 sebesar 4.92 GW atau $20 \%$ dari potensi.

Level 2

Mengasumsikan kapasitas pembangkit biomassa pada tahun 2050 sebesar $9.86 \mathrm{GW}$ atau $40 \%$ dari potensi.

Level 3

Level 3 mengasumsikan kapasitas pembangkit biomassa pada tahun 2050 mencapai 14.78 GW atau $60 \%$ dari potensi.

Level 4

Pada level ini kapasitas pembangkit biomassa pada tahun 2050 sebesar $22.18 \mathrm{GW}$ atau $90 \%$ dari potensi. Pada level 4 pemanfaatan biomassa untuk pembangkit hampir maksimal.

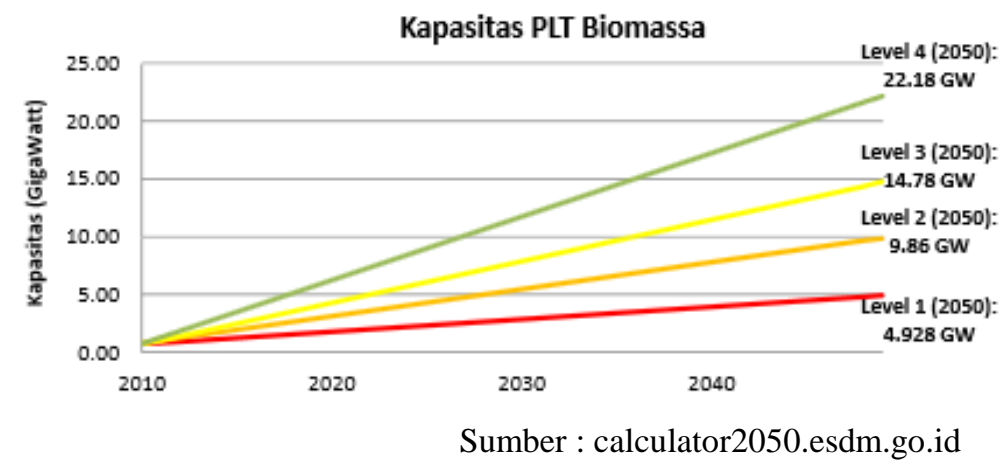

Gambar 7. Grafik Kapasitas PLT Biomassa Level I - IV

3. Tenaga air

Potensi tenaga air di Indonesia sebesar 26.32 GW, dalam kalkulator 2050 angka potensi yang digunakan adalah $75 \mathrm{GW}$.

Level 1

Pada level 1 mengasumsikan kapasitas terpasang untuk PLTA pada tahun 2050 sebesar 11.25 GW, pada level ini terdapat beberapa tantangan dalam pembangunan PLTA.

Level 2

Level 2 mengasumsikan kapasitas terpasan pembangkit tenaga air pada tahun 2050 sebesar 18.75 . 


\section{Rezzy Eko Caraka, Puti Cresti Ekacitta}

Level 3

Level 3 mengasumsikan kapasitas terpasang pembangkit tenaga air pada tahun 2050 sebesar $30 \mathrm{GW}$ atau sebesar $40 \%$ dari total potensi. Diasumsikan potensi pembangunan PLTA di Wilayah Indonesia Timur seperti Maluku dan Papua.

Level 4

Kapasitas PLTA pada tahun 2050 mencapai $41.25 \mathrm{GW}$ atau $55 \%$ dari potensi. Diasumsikan penggunaan pembangkit berbahan bakar fosil sudah tidak ekonomis lagi, sehingga memerlukan sumber lain untuk mengisi kekurangan.

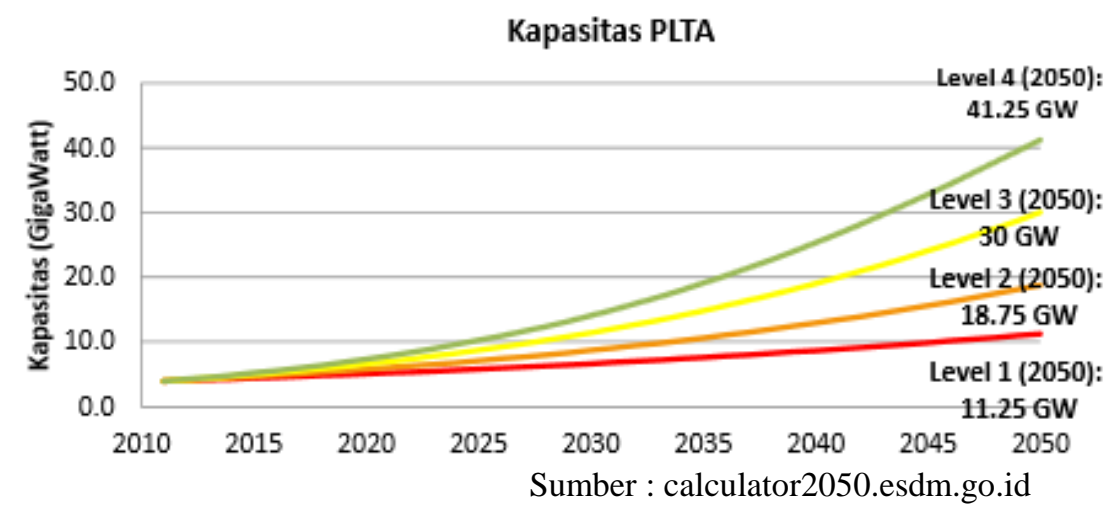

Gambar 8. Grafik Kapasitas PLA Biomassa Level I - IV

4. Tenaga Angin

Saat ini, energi angin merupakan salah satu sumber energi terbarukan yang belum mendapat perhatian cukup. Wilayah wilayah yang ditengarai memiliki kecepatan angin lebih dari $6 \mathrm{~m} / \mathrm{s}$ diantaranya ujung Pulau Sumatera, sebagian selatan pulau jawa, dan utara Pulau Sulawesi, diperkirakan potensi energi angin di Indoensia mencapai 61.97 GW.

Kapasitas PLTB

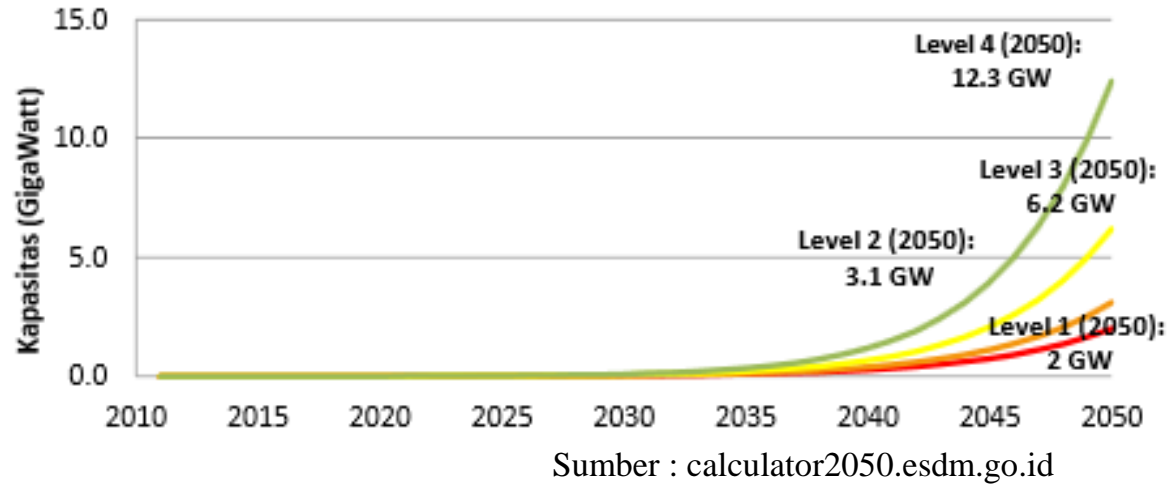

Gambar 9. Grafik Kapasitas PLTB Biomassa Level I - IV

5. Tenaga Surya

Di Indonesia, kapasitas terpasang PLTS pada tahun 2011 adalah $0.00116 \mathrm{GW}$, Indonesia memiliki durasi lama penyinaran matahari yang cukup lama antara $4-5$ jam. 


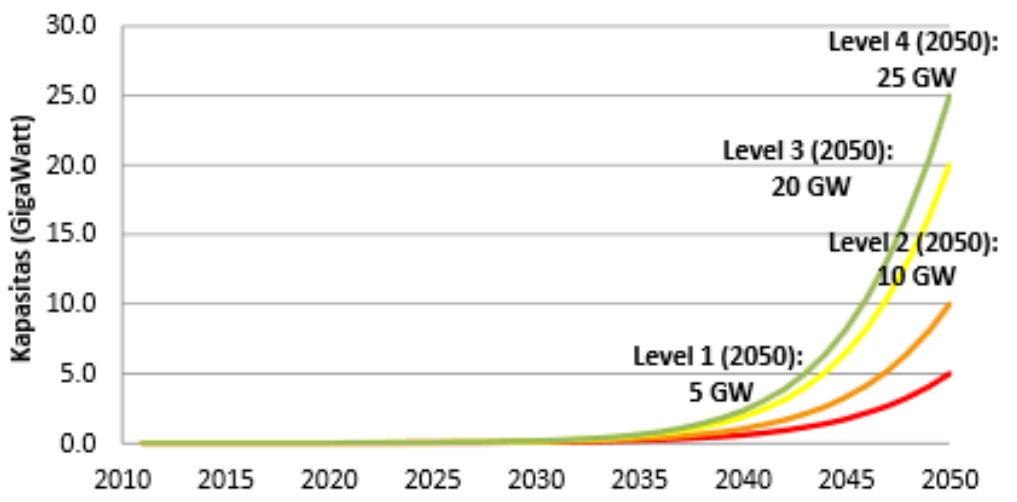

Gambar 10. Grafik Kapasitas PLTS Biomassa Level I - IV

\section{KESIMPULAN DAN REKOMENDASI}

\section{Kesimpulan}

1. Produksi batubara tahun 2050 sebesar 1.629 juta ton dengan kenaikan produksi sebesar $4 \%$. Produksi batubara digunakan terutama untuk memenuhi kebutuhan sektor ketenagalistrikan yang sangat tinggi untuk sektor industri yang jumlahnya terus meningkat.

2. Produksi minyak bumi mencapai 1 juta bpd, jumlah ini diasumsikan berasal dari penambahan produksi sebesar $23 \%$ dari potensi, juga adana proyek offshore pada tahun 2030, 2035 dan 2040

3. Produksi gas bumi pada tahun 2050 sebesar 9479 mmscfd. Produksi tersebut berasal dari tambahan produksi, antara lain project supply dan potential supply, penemuan gas baru sekitar $34 \%$ dari potensi dan produksi CBM sebesar $4 \%$.

4. Produksi biomassa pada tahun 2050 sebesar $22.18 \mathrm{GW}$ atau $90 \%$ dari potensi.

5. Kapasitas PLTA pada tahun 2050 mencapai $41.25 \mathrm{GW}$ atau $55 \%$ dari potensi. Diasumsikan penggunaan pembangkit berbahan bakar fosil sudah tidak ekonomis lagi, sehingga memerlukan sumber lain untuk mengisi kekurangan.

\section{Rekomendasi}

1. Perlu segera dibuat neraca sumber daya alam nasional (khususnya energi) sebagai acuan untuk memetakan seluruh ragam potensi dan produksi energi nasional di seluruh wilayah nusantara.

2. Perlu segera dipercepat pengembangan infrastruktur EBT sesuai dengan roadmap pencapaian bauran energi.

3. Segera dirumuskan dan diterapkan pola subsidi energi yang lebih tepat (untuk BBM dan non BBM), sehingga EBT memiliki nilai kompetitif.

4. Membenahi berbagai regulasi terkait dengan peraturan perundang undangan yang tidak efektif dan tumpang tindih.

5. Meningkatkan kinerja dan kapasitas kelembagaan yang berkaitan dengan pengembangan EBT, khususnya koordinasi antar instansi dan menghilangkan tumpang tindih kewenangan.

\section{DAFTAR PUSTAKA}

BPPT.2014. Outlook Energi Indonesia 2014.Badan Pengkajian dan Penerapan Teknologi,Jakarta.

Calculator2050.esdm.go.id/pathways

Caraka, R.E., Yasin, H. 2014. Prediksi Produksi Gas Bumi Dengan General Regression Neural Network (GRNN). Department of Statistics University of Padjadjaran. National Seminar 


\section{Rezzy Eko Caraka, Puti Cresti Ekacitta}

Statistics IV “ Implementation Statistics in the Exploration Energy". 1 November 2014 ISSN : 2087-2590 pp: 270-277

Inside,Pgn. 2013.Pengelolaan sumber daya alami strategis Indonesia - gas bumi, Edisi Khusus 59, $10-13$

KESDM.2014.Handbook of Energi and Economic Statistic of Indonesia.KESDM.Jakarta

Tumiran.2013.Road Map Menuju Kedaulatan Energi. Dewan Energi Nasional. Jakarta 